JURNAL ILMIAH AGRINECA

ISSN : 2721-074X (Online) - 2301-6698 (Print)

Available on : http://ejournal.utp.ac.id/index.php/AFP/index

This is Under CC BY SA Licence

\title{
ANALISIS PERTUMBUHAN KEDELAI VARIETAS GROBOGAN PADA CEKAMAN KEKERINGAN
}

\section{Growth Analysis Soybean Grobogan Variety under Drought Stress}

\author{
Achmad Fatchul Aziez ${ }^{1}$, Tyas Soemarah KD ${ }^{1}$, Teguh Supriyadi ${ }^{1}$, Angga Firman Saputra ${ }^{2 *}$ \\ ${ }^{1}$ Program Studi Agroteknologi, Fakultas Pertanian, Universitas Tunas Pembangunan \\ ${ }^{2 *}$ Mahasiswa Program Studi Agroteknologi, Fakultas Pertanian, Universitas Tunas Pembangunan \\ Surakarta \\ *Correspondent author : anggafs007@gmail.com
}

\begin{abstract}
Soybean (Glycine max (L.) Merril) is one of the main food commodities in Indonesia. Soybean production has not been able to meet domestic food needs, one of the causes is the existence of drought stress. The aim of this study was to analyze the growth of soybean plants at different levels of drought stress at various stages of growth. This research was conducted in a plastic house in Demangan village, Sambi district, Boyolali district from August to December 2020. The study used a completely randomized design with 2 factors and 3 replications. The first factor is soil moisture content ei. 100\%, 75\%, 50\% 25\% of field capacity. The second factor is the time of drought stress which includes the active vegetative phase, the flowering phase and the seed filling phase. The parameters observed were Leaf Area Index (LAI), Specific Leaf Area (SLA), Crop Growth Rate (CGR) and Net Assimilation Rate (NAR). The results of this study indicated that drought stress in the pod filling phase reduced LAI, SLA, NAR and $C G R$.
\end{abstract}

Keywords: Drought stress, growth analysis, growth phase, soil moisture, Soybeans.

\begin{abstract}
ABSTRAK
Kedelai (Glycine max (L.) Merril) merupakan salah satu komoditas pangan utama di Indonesia. Produksi kedelai belum mampu mencukupi kebutuhan pangan dalam negeri, salah satu penyebabnya adalah adanya cekaman kekeringan.Tujuan penelitian ini adalah untuk menganalisis pertumbuhan tanaman kedelai pada tingkat cekaman kekeringan yang berbeda pada berbagai fase pertumbuhannya. Penelitian ini dilaksanakan di rumah plastik desa Demangan, kecamatan Sambi kabupaten Boyolali pada bulan Agustus sampai Desember 2020. Penelitian menggunakan Rancangan Acak Lengkap 2 faktor dan 3 ulangan. Faktor pertama adalah kadar lengas tanah meliputi $100 \%, 75 \%, 50 \% 25 \%$ kapasitas lapang. Faktor kedua adalah saat terjadinya cekaman kekeringan meliputi fase Vegetatif Aktif, fase Pembungaan dan fase pengisian biji. Parameter yang diamati yaitu Indeks Luas Daun (ILD), Luas Daun Spesifik (LDS), Laju Pertumbuhan Tanaman (LPT) dan Laju Asimilasi Bersih (LAB). Hasil penelitian ini menunjukkan bahwa cekaman kekeringan pada fase pengisian polong menurunkan ILD, LDS, LAB dan LPT
\end{abstract}

Kata kunci : Analisis pertumbuhan, cekaman kekeringan, fase pertumbuhan, kedelai., lengas tanah

\section{PENDAHULUAN}

Indonesia merupakan salah satu negara yang dilalui garis khatulistiwa sehingga memiliki iklim tropis.Sektor pertanian merupakan sektor penting dalam perekonomian Negara Indonesia. Pada tahun 2019, sektor pertanian memiliki kontribusi sebesar 12,72\% dan menempati urutan ketiga dari PDB Indonesia (Badan Pusat Statistik, 2019). 
JURNAL ILMIAH AGRINECA

ISSN : 2721-074X (Online) - 2301-6698 (Print)

Available on : http://ejournal.utp.ac.id/index.php/AFP/index

This is Under CC BY SA Licence

Kedelai (Glycine max (L.) Merril) merupakan salah satu komoditas pangan utama di Indonesia. Kedelai menempati urutan ketiga setelah padi dan jagung sebagai tanaman pangan utama di Indonesia. Kedelai sebagai penyedia bahan pangan bergizi seperti protein dan dijuluki sebagai Gold from the soil atau World's Miracle (Mursidah, 2005). Kedelai kaya akan protein nabati sehingga menjadi komoditas yang penting untuk peningkatan gizi masyarakat. Dengan pertumbuhan penduduk yang terus bertambah akan sebanding dengan kebutuhan biji kedelai yang meningkat untuk bahan baku olahan pangan (tahu, tempe, kecap, susu kedelai, tauco dan sebagainya) (Permadi, 2014).

Saat ini rata-rata sebanyak 4,3 juta ton biji kering/tahun dibutuhkan untuk produksi bahan pangan berbahan dasar kedelai. Sementara itu, produksi dalam negeri rata-rata lima tahun terakhir sebesar 982,47 ribu ton biji kering atau 43\% dari kebutuhan. Defisit produksi terhadap kebutuhan menyebabkan harus impor (Balitkabi, 2018). Menurut data Badan Pusat Statistik tercatat impor kedelai Indonesia tahun 2018 sebesar 2,5 juta ton dan pada tahun 2019 sebesar 2,6 juta ton. Diperkirakan pada tahun 2020 akan meningkat jika belum ada peningkatan produktivitas kedelai dalam negeri (Badan Pusat Statistik, 2020).

Pergeseran pola hujan mempengaruhi sumberdaya dan infrastruktur pertanian yang menyebabkan bergesernya waktu tanam, musim, dan pola tanam. Pertanaman kedelai di Indonesia sebagian besar $(65 \%)$ di tanam di lahan sawah pada musim kemarau. Pada kondisi demikian, budidaya kedelai seringkali dihadapkan pada risiko kekeringan (BPPP Kemendag, 2011).

Varietas berperan penting dalam produksi kedelai, karena untuk mencapai hasil yang tinggi sangat ditentukan oleh potensi genetiknya. Varietas Grobogan berasal dari pemurnian populasi lokal Malabar Grobogan, potensi hasil panen dari varietas grobogan 3,40 ton/ha dan rata-rata hasil produksi 2,77 ton/ha. Pada umur 30-32 hari varietas Grobogan sudah berbunga pecah (Balitkabi, 2005 dalam Bertham et al., 2018).
Selain varietas, air juga sangat penting untuk kegiatan budidaya kedelai, karena dapat menunjang pertumbuhan tanaman. Oleh karena itu perlu untuk mengetahui sejauhmana tingkat kekeringan dapat mempengaruhi kedelai pada berbagai fase pertumbuhannya

\section{METODE PENELITIAN}

Penelitian ini menggunakan Rancangan Acak Lengkap dengan 3 ulangan yang terdiri dari 2 faktor yaitu : Faktor pertama, kadar lengas tanah : 100\%, $75 \%, 50 \% 25 \%$ kapasitas lapang. Faktor kedua, fase pertumbuhan yang terdiri fase vegetatif aktif, fase Pembungaan, dan fase pengisian biji.

Alat yang digunakan antara lain polybag ukuran $35 \times 35 \mathrm{~cm}$, oven, timbangan digital, gelas ukur, bambu, plastik transparan, Bahan meliputi benih kedelai Varietas Grobogan, Pupuk NPK mutiara (75 kg/ha), SP-36 (50 kg/ha), tanah regosol, pupuk hayati Rhzobium $(6,25 \mathrm{~g} / 500 \mathrm{~g}$ benih).

Penelitian ini dilaksanakan bulan Agustus sampai Desember 2020. di rumah plastik Desa Demangan, Kecamatan Sambi Kabupaten Boyolali pada ketinggian tempat $130 \mathrm{mdpl}$ dengan jenis tanah Regosol dan di Laboratorium Fakultas Pertanian Universitas Tunas Pembangunan Surakarta.

Pemberian perlakuan cekaman kekeringan dilakukan saat memasuki fase-fase dari tanaman kedelai. Untuk perlakuan diluar fase tersebut volume penyiramannya sesuai dengan kapasitas lapanganya atau $100 \%$ volume kapasitas lapang.

Pengamatan dilakukan pada minggu ke-4, ke-6, ke-8, ke-10 dan ke-12 atau panen dengan parameter: Indeks Luas Daun, Luas Daun Spesifik, Laju Pertumbuhan Tanaman dan Laju Asimilasi Bersih.

Analisis data dengan sidik ragam, dan apabila berbeda nyata antar perlakuan, maka dilakukan uji lanjut menggunakan uji jarak berganda Duncan Multiple Range Test (DMRT) dengan taraf $5 \%$ untuk membedakan antar perlakuan. 
HASIL DAN PEMBAHASAN

Tabel 1. Sidik Ragam parameter pengamatan

\begin{tabular}{|c|c|c|c|c|c|}
\hline \multirow{2}{*}{ Parameter Pengamatan } & \multirow{2}{*}{ Interval Waktu } & \multicolumn{4}{|c|}{ Sumber keragaman } \\
\hline & & $\mathrm{K}$ & $\mathrm{F}$ & $\mathrm{K} \times \mathrm{F}$ & Perlakuan \\
\hline \multirow{4}{*}{ Indeks Luas Daun } & $4-6 \mathrm{MST}$ & $* *$ & ns & $*$ & $* *$ \\
\hline & $6-8 \mathrm{MST}$ & $* *$ & ns & $*$ & $* *$ \\
\hline & $8-10 \mathrm{MST}$ & $*$ & ns & ns & $*$ \\
\hline & $10-12 \mathrm{MST}$ & $* *$ & ns & $*$ & $* *$ \\
\hline \multirow{4}{*}{ Luas Daun Spesifik } & 4-6 MST & $* *$ & ns & $*$ & $* *$ \\
\hline & $6-8 \mathrm{MST}$ & $*$ & ns & $*$ & $*$ \\
\hline & $8-10 \mathrm{MST}$ & $*$ & ns & $*$ & $*$ \\
\hline & $10-12 \mathrm{MST}$ & $* *$ & ns & ns & $*$ \\
\hline \multirow{4}{*}{ Laju Asimilasi Bersih } & 4-6 MST & $*$ & ns & $\mathrm{ns}$ & $*$ \\
\hline & $6-8 \mathrm{MST}$ & $* *$ & ns & $*$ & $* *$ \\
\hline & 8 - 10 MST & $*$ & ns & $*$ & $*$ \\
\hline & $10-12 \mathrm{MST}$ & $* *$ & ns & $*$ & $* *$ \\
\hline \multirow{4}{*}{ Laju Pertumbuhan Tanaman } & 4-6 MST & $* *$ & ns & ns & $*$ \\
\hline & $6-8 \mathrm{MST}$ & $*$ & ns & ns & $*$ \\
\hline & 8 - 10 MST & $* *$ & ns & $*$ & $* *$ \\
\hline & $10-12 \mathrm{MST}$ & $*$ & $\mathrm{~ns}$ & ns & $*$ \\
\hline
\end{tabular}

Sumber : Data Primer yang Diolah

Keterangan : $\mathrm{K}=$ kadar lengas tanah, $\mathrm{F}=\mathrm{Fase}$ Pertumbuhan,

$* *)=$ Berbeda sangat nyata, $*$ ) = berbeda nyata, ns) $=$ berbeda tidak nyata

Dari sidik ragam (Tabel 1), kadar lengas tanah semua parameter pengamatan menunjukkan perbedaan. Untuk fase pertumbuhan semua parameter tidak menunjukkan perbedaan. Terdapat interaksi kedua perlakuan kecuali ILD 8-10 MST, LDS 10-12 MST, LAB 4-6 MST, dan LPT 4-6 MST, 6-8 MST dan 10-12 MST.

\section{Indeks Luas Daun (ILD)}

Sitompul dan Guritno dalam Suryaningrum et al., (2016) menjelaskan bahwa indeks luas daun adalah perbandingan antar luas daun total dengan luas tanah yang ternaungi. Sedangkan Kadekoh dalam Sari (2008), besaran indeks luas daun menentukan kemampuan tanaman untuk mengintersepsi cahaya matahari. Indeks Luas Daun memiliki kaitan erat dengan kemampuan suatu tanaman menangkap cahaya untuk pertumbuhan dan perkembangannya, dimana cahaya memiliki peranan penting dalam proses fisiologis tanaman (Milianda, 2020).

Berdasarkan Tabel 2 nilai Indeks Luas Daun pada interval waktu 4-6 MST pengaruh interaksi kadar lengas tanah dan fase pertumbuhan berbeda nyata dengan nilai tertinggi K1F2 $(0,8478)$ dan nilai terendah K4F2 (0,3444). Untuk 6-8 MST nilai tertinggi K1F3 $(1,1399)$ dan nilai terendah K4F3 $(0,6944)$. Untuk 8-10 MST nilai tertinggi K1F3 $(1,3081)$ dan nilai terendah K4F3 (1,0064). Untuk 10-12 MST nilai tertinggi K1F3 $(0,9547)$ dan nilai terendah K4F3 (0,7107).

Menurut Erice et al., (2010) dalam Parwata et al., (2014) bahwa Cekaman kekeringan dapat menurunkan jumlah daun dan jika jumlah daun menurun maka dapat meyebabkan nilai Indeks Luas Daun juga rendah. Pendapat Cordeiro et al., 


\section{JURNAL ILMIAH AGRINECA}

ISSN : 2721-074X (Online) - 2301-6698 (Print)

Available on : http://ejournal.utp.ac.id/index.php/AFP/index

This is Under CC BY SA Licence

(2009) dalam Parwata et al., (2014) menjelaskan penurunan ini merupakan adaptasi dari tanaman untuk menjaga keseimbangan air. Namun, dengan hal tersebut maka laju fotosintesis akan menurun dan mempengaruhi pertumbuhannya. Nilai Indeks Luas Daun yang rendah mempunyai laju asimilasi $\mathrm{CO}_{2}$ yang rendah dan mentranslokasikan lebih sedikit asimilasi kepada bagian lain (Ningrum, 2011).
Menurut Verasan dan Philips (1978) dalam Zulfita (2012) bahwa daun memiliki respon cepat terhadap kekurangan kadar air. Akibat kekeringan, tanaman melakukan mekanisme pertahanan dengan menurunkan luas daunnya (Goldworthy dan Fisher, 1984 dalam Zulfita, 2012). Luas daun rendah maka nilai Indeks Luas Daun rendah sehingga kemampuan tanaman dalam menyerap cahaya tidak optimal.

Tabel 2. Indek Luas Daun pada berbagai kadar lengas tanah dan fase pertumbuhan

\begin{tabular}{|c|c|c|c|c|}
\hline \multirow{2}{*}{ Perlakuan } & \multicolumn{4}{|c|}{ Interval Waktu } \\
\hline & $4-6 \mathrm{MST}$ & $6-8 \mathrm{MST}$ & $8-10 \mathrm{MST}$ & $10-12 \mathrm{MST}$ \\
\hline \multicolumn{5}{|c|}{ Kadar lengas tanah $(\mathrm{K})$} \\
\hline K1 & $2,2861 \mathrm{~d}$ & $3,2336 \mathrm{~d}$ & $3,7617 \mathrm{c}$ & $2,7337 \mathrm{~d}$ \\
\hline K2 & $2,1366 \mathrm{bc}$ & $2,9681 \mathrm{c}$ & $3,7457 \mathrm{c}$ & $2,6292 \mathrm{c}$ \\
\hline K3 & $1,9144 \mathrm{~b}$ & $2,7238 \mathrm{~b}$ & $3,5747 \mathrm{~b}$ & $2,4104 \mathrm{~b}$ \\
\hline K4 & $1,6057 \mathrm{a}$ & $2,5200 \mathrm{a}$ & $3,4535 \mathrm{a}$ & $2,2682 \mathrm{a}$ \\
\hline \multicolumn{5}{|c|}{ Fase Pertumbuhan $(\mathrm{F})$} \\
\hline F1 & $2,0223 \mathrm{a}$ & $2,9002 \mathrm{a}$ & $3,6917 \mathrm{a}$ & $2,5655 \mathrm{a}$ \\
\hline $\mathrm{F} 2$ & 1,8787 a & $2,9025 \mathrm{a}$ & $3,6179 \mathrm{a}$ & $2,5013 \mathrm{a}$ \\
\hline $\mathrm{F} 3$ & $2,0561 \mathrm{a}$ & $2,7815 \mathrm{a}$ & $3,5922 \mathrm{a}$ & $2,4644 \mathrm{a}$ \\
\hline \multicolumn{5}{|c|}{ Interaksi Kadar lengas tanah dan Fase Pertumbuhan $(\mathrm{K} \times \mathrm{F})$} \\
\hline K1F1 & 0,7467 b-e & $0,9554 \mathrm{~b}-\mathrm{e}$ & $1,2110 \mathrm{~b}-\mathrm{d}$ & $0,8766 \mathrm{~d}-\mathrm{f}$ \\
\hline $\mathrm{K} 1 \mathrm{~F} 2$ & 0,8478 e & $1,1383 \mathrm{e}$ & $1,2426 \mathrm{~b}-\mathrm{d}$ & $0,9025 \mathrm{~d}-\mathrm{f}$ \\
\hline $\mathrm{K} 1 \mathrm{~F} 3$ & $0,6916 \mathrm{~b}-\mathrm{e}$ & $1,1399 \mathrm{e}$ & $1,3081 \mathrm{~d}$ & $0,9547 \mathrm{f}$ \\
\hline $\mathrm{K} 2 \mathrm{~F} 1$ & $0,7290 \mathrm{~b}-\mathrm{e}$ & $0,9428 \mathrm{~b}-\mathrm{e}$ & $1,2611 \mathrm{~b}-\mathrm{d}$ & $0,8695 \mathrm{~d}-\mathrm{f}$ \\
\hline $\mathrm{K} 2 \mathrm{~F} 2$ & $0,7031 \mathrm{~b}-\mathrm{e}$ & 0,9997 b-e & $1,2223 \mathrm{~b}-\mathrm{d}$ & $0,8587 \mathrm{~d}-\mathrm{f}$ \\
\hline $\mathrm{K} 2 \mathrm{~F} 3$ & $0,7045 \mathrm{~b}-\mathrm{e}$ & $1,0256 \mathrm{~b}-\mathrm{e}$ & $1,2623 \mathrm{~b}-\mathrm{d}$ & $0,9011 \mathrm{~d}-\mathrm{f}$ \\
\hline $\mathrm{K} 3 \mathrm{~F} 1$ & $0,5892 \mathrm{~b}$ & $0,9970 \mathrm{~b}-\mathrm{e}$ & $1,2189 \mathrm{~b}-\mathrm{d}$ & $0,8606 \mathrm{~d}-\mathrm{f}$ \\
\hline $\mathrm{K} 3 \mathrm{~F} 2$ & $0,6096 \mathrm{bc}$ & $0,8781 \mathrm{a}-\mathrm{d}$ & $1,2031 \mathrm{~b}-\mathrm{d}$ & $0,8303 \mathrm{c}-\mathrm{e}$ \\
\hline K3F3 & $0,7157 \mathrm{~b}-\mathrm{e}$ & $0,8487 \mathrm{ab}$ & $1,1527 \mathrm{ab}$ & $0,7195 a b$ \\
\hline $\mathrm{K} 4 \mathrm{~F} 1$ & $0,6316 \mathrm{~b}-\mathrm{e}$ & $0,9717 \mathrm{~b}-\mathrm{e}$ & 1,2312 b-d & $0,8140 \mathrm{~b}-\mathrm{d}$ \\
\hline K4F2 & $0,3444 \mathrm{a}$ & $0,8539 \mathrm{a}-\mathrm{c}$ & $1,1558 \mathrm{abc}$ & $0,7436 \mathrm{a}-\mathrm{c}$ \\
\hline K4F3 & $0,6297 \mathrm{~b}-\mathrm{d}$ & $0,6944 \mathrm{a}$ & $1,0664 \mathrm{a}$ & $0,7107 \mathrm{a}$ \\
\hline
\end{tabular}

Keterangan : Perlakuan pada kolom yang sama dan diikuti dengan huruf yang sama menunjukkan berbeda tidak nyata menurut DMRT 5\%

\section{Luas Daun Spesifik (LDS)}

Luas Daun Spesifik merupakan perbandingan antara luas daun dengan bobot daun (Sakya et al., 2015). Menurut Suryaningrum et al., (2016) bahwa Nilai Luas Daun Spesifik memberikan petunjuk tentang ketebalan daun tanaman. Luas Daun Spesifik dapat mengetahui efisiensi pembentukan luas daun per satuan karbohidrat yang tersedia (Rahmatullah, 2011).
Berdasarkan Tabel 3 nilai LDS pada interval waktu 4-6 MST untuk pengaruh interaksi antara kadar lengas tanah dan fase pertumbuhan berbeda nyata dengan nilai tertinggi K1F2 $\left(322,21 \mathrm{~cm}^{2} / \mathrm{g}\right)$ dan nilai terendah K4F2 $\left(199,66 \mathrm{~cm}^{2} / \mathrm{g}\right)$. Untuk 68 MST nilai tertinggi K1F3 $\left(270,45 \mathrm{~cm}^{2} / \mathrm{g}\right)$ dan nilai terendah K4F3 $\left(169,87 \mathrm{~cm}^{2} / \mathrm{g}\right.$. Untuk $8-10$ MST nilai tertinggi K1F3 $\left(297,45 \mathrm{~cm}^{2} / \mathrm{g}\right)$ dan nilai terendah K4F3 $\left(156,77 \mathrm{~cm}^{2} / \mathrm{g}\right)$. Untuk 10-12 MST nilai tertinggi K1F3 $\left(278,89 \mathrm{~cm}^{2} / \mathrm{g}\right)$ dan nilai terendah K4F3 $\left(102,95 \mathrm{~cm}^{2} / \mathrm{g}\right)$. 
Tabel 3. Luas Daun Spesifik pada berbagai kadar lengas tanah dan fase pertumbuhan $\left(\mathrm{cm}^{2} / \mathrm{g}\right)$

\begin{tabular}{|c|c|c|c|c|}
\hline \multirow{3}{*}{ Perlakuan } & \multicolumn{4}{|c|}{ Umur Pengamatan } \\
\hline & $4-6 \mathrm{MST}$ & $6-8 \mathrm{MST}$ & $8-10 \mathrm{MST}$ & $10-12 \mathrm{MST}$ \\
\hline & \multicolumn{4}{|c|}{ Kadar lengas tanah $(\mathrm{K})$} \\
\hline K1 & $908,75 \mathrm{~d}$ & $738,45 \mathrm{~d}$ & $786,84 \mathrm{~b}$ & $760,13 \mathrm{~d}$ \\
\hline $\mathrm{K} 2$ & $851,59 \mathrm{~b}$ & $689,67 \mathrm{bc}$ & $787,66 \mathrm{~b}$ & $547,75 \mathrm{bc}$ \\
\hline K3 & $853,18 \mathrm{bc}$ & $682,88 \mathrm{~b}$ & $750,08 \mathrm{~b}$ & $580,33 \mathrm{~b}$ \\
\hline K4 & $752,23 \mathrm{a}$ & $617,07 \mathrm{a}$ & $645,81 \mathrm{a}$ & $455,62 \mathrm{a}$ \\
\hline \multicolumn{5}{|c|}{ Fase Pertumbuhan $(\mathrm{F})$} \\
\hline $\mathrm{F} 1$ & $850,82 \mathrm{a}$ & $693,61 \mathrm{a}$ & $772,44 \mathrm{a}$ & $594,90 \mathrm{a}$ \\
\hline $\mathrm{F} 2$ & $827,34 \mathrm{a}$ & $679,18 \mathrm{a}$ & $722,59 \mathrm{a}$ & $588,98 \mathrm{a}$ \\
\hline F3 & $846,15 \mathrm{a}$ & $673,27 \mathrm{a}$ & $732,77 \mathrm{a}$ & $573,99 \mathrm{a}$ \\
\hline \multicolumn{5}{|c|}{ Interaksi Kadar lengas tanah dan Fase Pertumbuhan (K x F) } \\
\hline $\mathrm{K} 1 \mathrm{~F} 1$ & $287,89 \mathrm{~b}-\mathrm{d}$ & $230,58 \mathrm{~b}-\mathrm{e}$ & $247,30 \mathrm{bc}$ & $226,07 \mathrm{~b}-\mathrm{e}$ \\
\hline $\mathrm{K} 1 \mathrm{~F} 2$ & $322,21 \mathrm{~d}$ & $237,42 \mathrm{~b}-\mathrm{e}$ & $242,10 \mathrm{bc}$ & $255,17 \mathrm{~b}-\mathrm{e}$ \\
\hline $\mathrm{K} 1 \mathrm{~F} 3$ & 298,65 b-d & $270,45 \mathrm{e}$ & $297,45 \mathrm{c}$ & $278,89 \mathrm{e}$ \\
\hline $\mathrm{K} 2 \mathrm{~F} 1$ & $275,59 \mathrm{bc}$ & $232,83 \mathrm{~b}-\mathrm{e}$ & $272,64 \mathrm{bc}$ & $235,88 \mathrm{~b}-\mathrm{e}$ \\
\hline $\mathrm{K} 2 \mathrm{~F} 2$ & $292,05 \mathrm{~b}-\mathrm{d}$ & $225,72 \mathrm{~b}-\mathrm{e}$ & $242,15 \mathrm{bc}$ & 169,91 a-d \\
\hline $\mathrm{K} 2 \mathrm{~F} 3$ & $283,95 \mathrm{~b}-\mathrm{d}$ & $231,11 \mathrm{~b}-\mathrm{e}$ & $272,87 \mathrm{bc}$ & $220,59 \mathrm{~b}-\mathrm{e}$ \\
\hline $\mathrm{K} 3 \mathrm{~F} 1$ & $282,95 \mathrm{~b}-\mathrm{d}$ & 236,48 b-e & $268,35 \mathrm{bc}$ & 224,67 b-e \\
\hline $\mathrm{K} 3 \mathrm{~F} 2$ & $289,20 \mathrm{~b}-\mathrm{d}$ & 220,14 b-e & $231,79 \mathrm{bc}$ & 192,78 b-e \\
\hline K3F3 & 281,04 b-d & 226,26 b-e & $249,94 \mathrm{bc}$ & $162,88 \mathrm{ab}$ \\
\hline $\mathrm{K} 4 \mathrm{~F} 1$ & $288,00 \mathrm{~b}-\mathrm{d}$ & $224,92 \mathrm{~b}-\mathrm{d}$ & $241,63 \mathrm{bc}$ & 185,21 a-e \\
\hline $\mathrm{K} 4 \mathrm{~F} 2$ & 199,66 a & $222,28 \mathrm{bc}$ & $247,41 \mathrm{bc}$ & 167,45 a-c \\
\hline $\mathrm{K} 4 \mathrm{~F} 3$ & $264,56 \mathrm{~b}$ & $169,87 \mathrm{a}$ & $156,77 \mathrm{a}$ & $102,95 \mathrm{a}$ \\
\hline
\end{tabular}

Keterangan : Perlakuan pada kolom yang sama dan diikuti dengan huruf yang sama menunjukkan berbeda tidak nyata menurut DMRT 5\%

Cekaman kekeringan menurunkan jumlah daun, luas daun, luas daun spesifik dan bobot kering tanaman (Farooq et al., 2010 dalam Sulistyono et al., 20012). Widiatmoko et al., (2012) menambahkan bahwa kekeringan akan menurunkan jumlah daun karena bertujuan untuk menjaga potensial air pada tanaman. Jumlah daun mempengaruhi luas daun, apabila jumlahnya sedikit maka luas daun totalnya juga rendah (Santoso et al., 2018). Dengan rendahnya luas daun total tiap tanaman, maka Luas Daun Spesifiknya akan rendah. Sehingga penyerapan cahaya akan terganggu. Intensitas cahaya juga memiliki pengaruh terhadap pertumbuhan tanaman tergantung seberapa banyaknya cahaya yang mampu diserap tanaman Gardner et al., 1991 dalam Maulana, 2018). Diperkuat lagi oleh penelitian David, (2008) bahwa terdapat korelasi postif antara kadar lengas tanah dengan Luas Daun Spesifik yaitu $\left(\mathrm{R}^{2}=0,99\right)$ artinya semakin rendah kadar lengas tanah maka Luas Daun Spesifiknya akan menurun.

\section{Laju Pertumbuhan Tanaman}

Laju Pertumbuhan Tanaman merupakan peningkatan bahan kering hasil asimilasi tanaman dalam satuan luas lahan dan satuan waktu (Dartius, 2005 dalam Pramanda, 2019). Berdasarkan Tabel 4 nilai Laju Pertumbuhan Tanaman pada interval waktu 4-6 MST nilai tertinggi $\mathrm{K} 1 \mathrm{~F} 2\left(3,18 \mathrm{mg} / \mathrm{cm}^{2} / \mathrm{minggu}\right)$ dan nilai terendah $\mathrm{K} 4 \mathrm{~F} 2\left(1,88 \mathrm{mg} / \mathrm{cm}^{2} / \mathrm{minggu}\right)$. Untuk $6-8$ MST nilai tertinggi K1F3 $\left(3,78 \mathrm{mg} / \mathrm{cm}^{2} / \mathrm{minggu}\right)$ dan terendah K4F3 $\left(1,89 \mathrm{mg} / \mathrm{cm}^{2} /\right.$ minggu). Untuk 


\section{JURNAL ILMIAH AGRINECA}

ISSN : 2721-074X (Online) - 2301-6698 (Print)

Available on : http://ejournal.utp.ac.id/index.php/AFP/index

This is Under CC BY SA Licence

8-10 MST nilai tertinggi K1F3 (2,21 $\left.\mathrm{mg} / \mathrm{cm}^{2} / \mathrm{minggu}\right)$ dan nilai terendah $\mathrm{K} 4 \mathrm{~F} 3 \quad(1,41$ $\mathrm{mg} / \mathrm{cm}^{2} /$ minggu). Untuk 10-12 MST nilai tertinggi $\mathrm{K} 1 \mathrm{~F} 3\left(-1,89 \mathrm{mg} / \mathrm{cm}^{2} / \mathrm{minggu}\right)$ dan nilai terendah $\mathrm{K} 4 \mathrm{~F} 3\left(-3,35 \mathrm{mg} / \mathrm{cm}^{2} / \mathrm{minggu}\right)$.

Menurut Jumin (1992) dalam Marsha et al., (2014) bahwa pemberian air yang sedikit tidak akan mampu mencukupi untuk berbagai kebutuhan tanaman dalam pertumbuhan dan perkembangannya. Kondisi cekaman kekeringan ini menjadikan tanaman terganggu dalam melakukan transpor unsur hara untuk proses biokimia, sehingga akan menurunkan kemampuan tanaman dalam melakukan pertumbuhan dan

Tabel 4. Laju Pertumbuhan Tanaman pada berbagai kadar lengas tanah dan fase pertumbuhan $\left(\mathrm{mg} / \mathrm{cm}^{2} / \mathrm{minggu}\right)$.

\begin{tabular}{|c|c|c|c|c|}
\hline \multirow{3}{*}{ Perlakuan } & \multicolumn{4}{|c|}{ Umur Pengamatan } \\
\hline & $4-6 \mathrm{MST}$ & $6-8 \mathrm{MST}$ & $8-10 \mathrm{MST}$ & $10-12 \mathrm{MST}$ \\
\hline & \multicolumn{3}{|c|}{ Kadar lengas tanah (K) } & \\
\hline K1 & $8,58 \mathrm{~d}$ & $9,82 \mathrm{c}$ & $6,01 \mathrm{c}$ & $-6,71 c$ \\
\hline $\mathrm{K} 2$ & $7,73 \mathrm{bc}$ & $9,04 \mathrm{c}$ & $5,86 \mathrm{c}$ & $-7,18$ bc \\
\hline K3 & $7,06 \mathrm{~b}$ & $7,44 \mathrm{ab}$ & $5,37 \mathrm{~b}$ & $-7,89 a b$ \\
\hline K4 & $6,31 \mathrm{a}$ & $7,35 \mathrm{a}$ & $4,64 \mathrm{a}$ & $-8,27 \mathrm{a}$ \\
\hline \multicolumn{5}{|c|}{ Fase Pertumbuhan $(\mathrm{F})$} \\
\hline F1 & $7,56 \mathrm{a}$ & $8,41 \mathrm{a}$ & $5,61 \mathrm{a}$ & $-7,43 \mathrm{a}$ \\
\hline $\mathrm{F} 2$ & $7,06 \mathrm{a}$ & $8,68 \mathrm{a}$ & $5,53 \mathrm{a}$ & $-7,40 \mathrm{a}$ \\
\hline F3 & $7,65 \mathrm{a}$ & $8,15 \mathrm{a}$ & $5,27 \mathrm{a}$ & $-7,72 \mathrm{a}$ \\
\hline \multicolumn{5}{|c|}{ Interaksi Kadar lengas tanah (K) dan Fase Pertumbuhan (K x F) } \\
\hline K1F1 & $2,72 \mathrm{c}-\mathrm{f}$ & $2,71 \mathrm{a}-\mathrm{f}$ & $1,94 \mathrm{de}$ & $-2,31 b-d$ \\
\hline $\mathrm{K} 1 \mathrm{~F} 2$ & $3,18 \mathrm{f}$ & $3,33 \mathrm{~b}-\mathrm{f}$ & $1,86 \mathrm{~b}-\mathrm{e}$ & $-2,52 b-d$ \\
\hline $\mathrm{K} 1 \mathrm{~F} 3$ & $2,68 \mathrm{c}-\mathrm{f}$ & $3,78 \mathrm{f}$ & $2,21 \mathrm{e}$ & $-1,89 \mathrm{~d}$ \\
\hline $\mathrm{K} 2 \mathrm{~F} 1$ & $2,74 \mathrm{c}-\mathrm{f}$ & $3,22 b-f$ & $1,86 \mathrm{~b}-\mathrm{e}$ & $-2,33 b-d$ \\
\hline $\mathrm{K} 2 \mathrm{~F} 2$ & $2,46 \mathrm{a}-\mathrm{f}$ & $3,04 b-f$ & $2,14 \mathrm{e}$ & $-2,52 b-d$ \\
\hline $\mathrm{K} 2 \mathrm{~F} 3$ & $2,52 \mathrm{a}-\mathrm{f}$ & $2,78 \mathrm{a}-\mathrm{f}$ & $1,86 \mathrm{~b}-\mathrm{e}$ & $-2,33 b-d$ \\
\hline $\mathrm{K} 3 \mathrm{~F} 1$ & 2,40 a-e & $2,40 a b$ & $2,00 \mathrm{de}$ & $-2,70$ a-c \\
\hline $\mathrm{K} 3 \mathrm{~F} 2$ & $1,89 a b$ & 2,62 a-e & $1,83 \mathrm{~b}-\mathrm{e}$ & $-2,46 b-d$ \\
\hline K3F3 & $2,76 \mathrm{c}-\mathrm{f}$ & $2,42 \mathrm{a}-\mathrm{c}$ & $1,54 a b$ & $-2,73 a b$ \\
\hline $\mathrm{K} 4 \mathrm{~F} 1$ & $2,21 \mathrm{a}-\mathrm{c}$ & $2,88 \mathrm{~b}-\mathrm{f}$ & $1,68 \mathrm{a}-\mathrm{d}$ & $-2,56 b-d$ \\
\hline $\mathrm{K} 4 \mathrm{~F} 2$ & $1,88 \mathrm{a}$ & $2,58 \mathrm{a}-\mathrm{d}$ & $1,55 \mathrm{a}-\mathrm{c}$ & $-2,36 b-d$ \\
\hline K4F3 & $2,23 \mathrm{a}-\mathrm{d}$ & $1,89 \mathrm{a}$ & $1,41 \mathrm{a}$ & $-3,35 \mathrm{a}$ \\
\hline
\end{tabular}

Keterangan : Perlakuan pada kolom yang sama dan diikuti dengan huruf yang sama menunjukkan berbeda tidak nyata menurut DMRT 5\%

\section{Laju Asimilasi Bersih (LAB)}

Laju Asimilasi Bersih merupakan ukuran ratarata efisiensi fotosintesis daun dalam suatu komunitas tanaman (Gardner et al., 1991 dalam Suryaningrum et al., 2016). Laju Asimilasi Bersih menghasilkan bobot kering nantinya (Darwati et al., 2002 dalam Marsha et al., 2014). Kekurangan air dapat mengakibatkan Laju Pertumbuhan Tanaman menjadi rendah. Ketersediaan air yang rendah menyebabkan penurunan evapotranspirasi. Karena terdapat korelasi positif antara evapotranspirasi dengan produksi tanaman maka bila evapotranspirsi rendah akan menurunkan produksi tanaman (Sulistyono et al., 2007 dalam Sulistyono et al., 2012). 
JURNAL ILMIAH AGRINECA

ISSN : 2721-074X (Online) - 2301-6698 (Print)

Available on : http://ejournal.utp.ac.id/index.php/AFP/index

This is Under CC BY SA Licence

Tabel 5. Laju Asimilasi Bersih pada berbagai kadar lengas tanah dan fase pertumbuhan ( $\left.\mathrm{mg} / \mathrm{cm}^{2} / \mathrm{minggu}\right)$

\begin{tabular}{|c|c|c|c|c|}
\hline \multirow{2}{*}{ Perlakuan } & \multicolumn{4}{|c|}{ Umur Pengamatan } \\
\hline & 4-6 MST & $6-8 \mathrm{MST}$ & $8-10 \mathrm{MST}$ & $10-12 \mathrm{MST}$ \\
\hline \multicolumn{5}{|c|}{ Kadar lengas tanah $(\mathrm{K})$} \\
\hline $\mathrm{K} 1$ & $13,94 \mathrm{~b}$ & $9,06 \mathrm{c}$ & $5,28 \mathrm{c}$ &,$- 84 \mathrm{c}$ \\
\hline $\mathrm{K} 2$ & $13,96 \mathrm{~b}$ & $8,65 \mathrm{c}$ & $4,97 \mathrm{bc}$ & $-7,35 \mathrm{c}$ \\
\hline $\mathrm{K} 3$ & $12,33 \mathrm{~b}$ & $6,89 a b$ & $4,53 \mathrm{~b}$ & $-9,36 \mathrm{ab}$ \\
\hline K4 & $9,52 \mathrm{a}$ & $6,06 \mathrm{a}$ & $3,96 \mathrm{a}$ & $-10,08 \mathrm{a}$ \\
\hline \multicolumn{5}{|c|}{ Fase Pertumbuhan $(\mathrm{F})$} \\
\hline $\mathrm{F} 1$ & $12,03 \mathrm{a}$ & 7,96 a & $4,63 \mathrm{a}$ & $-8,48$ a \\
\hline $\mathrm{F} 2$ & $12,49 \mathrm{a}$ & $7,86 \mathrm{a}$ & $4,75 \mathrm{a}$ & $-8,59 \mathrm{a}$ \\
\hline $\mathrm{F} 3$ & $12,80 \mathrm{a}$ & $7,18 \mathrm{a}$ & $4,58 \mathrm{a}$ & $-8,91 \mathrm{a}$ \\
\hline \multicolumn{5}{|c|}{ Interaksi Kadar lengas tanah (K) dan Fase Pertumbuhan (K x F) } \\
\hline $\mathrm{K} 1 \mathrm{~F} 1$ & $3,32 \mathrm{ab}$ & $3,07 \mathrm{de}$ & $1,68 \mathrm{~b}-\mathrm{f}$ & $-2,47 \mathrm{c}-\mathrm{e}$ \\
\hline $\mathrm{K} 1 \mathrm{~F} 2$ & $5,60 \mathrm{~d}$ & $2,44 \mathrm{a}-\mathrm{d}$ & $1,51 \mathrm{a}-\mathrm{f}$ & $-3,18$ a-d \\
\hline K1F3 & $5,02 \mathrm{~b}-\mathrm{d}$ & 3,55 e & $2,08 \mathrm{f}$ & $-2,19 \mathrm{e}$ \\
\hline $\mathrm{K} 2 \mathrm{~F} 1$ & $4,51 \mathrm{~b}-\mathrm{d}$ & 3,10 de & $1,45 \mathrm{a}-\mathrm{f}$ & $-2,77 b-e$ \\
\hline $\mathrm{K} 2 \mathrm{~F} 2$ & $4,65 \mathrm{~b}-\mathrm{d}$ & $2,84 \mathrm{c}-\mathrm{e}$ & $1,92 b-f$ & $-2,28$ e \\
\hline $\mathrm{K} 2 \mathrm{~F} 3$ & $4,80 \mathrm{~b}-\mathrm{d}$ & $2,71 \mathrm{~b}-\mathrm{e}$ & $1,60 \mathrm{~b}-\mathrm{f}$ & $-2,30 \mathrm{e}$ \\
\hline $\mathrm{K} 3 \mathrm{~F} 1$ & 4,02 b-d & $2,55 \mathrm{~b}-\mathrm{e}$ & $1,64 b-f$ & $-2,86$ b-e \\
\hline $\mathrm{K} 3 \mathrm{~F} 2$ & 4,46 b-d & 2,61 b-e & $1,35 \mathrm{ab}$ & $-2,98$ b-e \\
\hline K3F3 & $3,85 \mathrm{~b}-\mathrm{d}$ & $1,73 \mathrm{ab}$ & $1,41 \mathrm{a}-\mathrm{d}$ & $-3,51 a b$ \\
\hline K4F1 & $4,18 \mathrm{~b}-\mathrm{d}$ & 1,89 a-c & $1,40 \mathrm{a}-\mathrm{c}$ & $-3,20 a-c$ \\
\hline $\mathrm{K} 4 \mathrm{~F} 2$ & $1,94 \mathrm{a}$ & 2,60 b-e & $1,55 \mathrm{a}-\mathrm{f}$ & $-3,01 b-e$ \\
\hline K4F3 & $3,40 \mathrm{a}-\mathrm{c}$ & $1,58 \mathrm{a}$ & $1,01 \mathrm{a}$ & $-3,87 \mathrm{a}$ \\
\hline
\end{tabular}

Keterangan : Perlakuan pada kolom yang sama dan diikuti dengan huruf yang sama menunjukkan berbeda tidak nyata menurut DMRT 5\%

Berdasarkan Tabel 5 nilai Laju Asimilasi Bersih pada interval waktu 4-6 MST interaksi kadar lengas tanah dan fase pertumbuhan berbeda tidak nyata dengan nilai tertinggi K1F2 $(5,60$ $\mathrm{mg} / \mathrm{cm}^{2} /$ minggu) dan nilai terendah K4F2 (1,94 $\mathrm{mg} / \mathrm{cm}^{2} /$ minggu). Untuk 6-8 MST nilai tertinggi $\mathrm{K} 1 \mathrm{~F} 3\left(3,55 \mathrm{mg} / \mathrm{cm}^{2} / \mathrm{minggu}\right)$ dan nilai terendah K4F3 $\left(1,58 \mathrm{mg} / \mathrm{cm}^{2} / \mathrm{minggu}\right)$. Untuk 8-10 MST nilai tertinggi $\mathrm{K} 1 \mathrm{~F} 3\left(2,08 \mathrm{mg} / \mathrm{cm}^{2} / \mathrm{minggu}\right)$ dan nilai terendah K4F3 $\left(1,01 \mathrm{mg} / \mathrm{cm}^{2} /\right.$ minggu $)$. Untuk 10-12 MST nilai tertinggi K1F3 $(-2,19$ $\mathrm{mg} / \mathrm{cm}^{2} /$ minggu) dan nilai terendah K4F3 $(-3,87$ $\mathrm{mg} / \mathrm{cm}^{2} /$ minggu).

Pengaruh kadar lengas tanah yang rendah dapat mempercepat penuaan daun dan menurunkan kandungan klorofilmya (Zaharieva et al., 2001 dalam Kristanto, et al., 2014). Cekaman kekeringan mengakibatkan terhambatnya laju fotosintesis sehingga asimilat yang dihasilkan menjadi rendah (Nasrudin et al., 2020). Laju Asimilasi yang tinggi akan menghasilkan bobot kering yang tinggi juga begitu juga sebaliknya. Rendahnya Laju Asimilasi Bersih akan berpengaruh terhadap rendahnya produktivitas tanaman (Firmansyah et al,.2016). Laju Asimilasi Bersih naik maka Laju Pertumbuhan Tanaman juga akan naik (Hariandi et al., 2019).

Hal ini menandakan bahwa cekaman kekeringan memiliki pengaruh terhadap pertumbuhan tanaman. Sejalan dengan pendapat dari Islami et al., 1995 dalam Subantoro, 2014) bahwa kekeringan mempengaruhi semua aspek pertumbuhan tanaman yaitu proses-proses fisiologis, biokimia, modifikasi anatomi dan morfologi tanaman.

Dari ketiga fase pertumbuhan berbeda tidak nyata. Namun, cekaman kekeringan pada fase pengisian polong hasilnya paling rendah. Karena 
JURNAL ILMIAH AGRINECA

ISSN : 2721-074X (Online) - 2301-6698 (Print)

Available on : http://ejournal.utp.ac.id/index.php/AFP/index

This is Under CC BY SA Licence

saat pengisian polong perlu banyak air untuk pembentukan biji. Sejalan dengan pendapat dari Fachrudin (2000) dalam Maimunah et al., (2018). Bahwa kekurangan air pada saat fase pengisian polong lebih terlihat terlihat efek negatifnya terhadap tanaman, karena tanaman perlu air untuk mencukupi akumulasi dari fotosintat untuk pembentukkan polong dan biji.

\section{KESIMPULAN}

Dari hasil penelitian ini dapat disimpulkan bahwa kadar lengas tanah $25 \%$ kapasitas lapang menurunkan ILD, LDS, LPT dan LAB, dan saat terjadinya cekaman kekeringan berdasarkan fase pertumbuhan tidak berbeda terhadap semua parameter yang diamati. Nilai terendah pada semua parameter yang diamati yaitu pada kadar lengas tanah 25\% kapasitas lapang pada saat pengisian polong.

\section{DAFTAR PUSTAKA}

Balitkabi. 2018. Kedelai. Sinar Tani 3(3733).

Bertham, Y.H., Nuraini, Murcitro, B.G. dan Nusantara, A.D. 2018. Uji Coba Empat Varietas Kedelai di Kawasan Pesisir Berbasis Biokompos. Jurnal Ilmiah Biologi Biogenesis. 6(1): 36-42.

BPS. 2020. Impor Kedelai Menurut Negara Asal 20102019. Badan Pusat Statistik Republik Indonesia. Jakarta.

BPS. 2019. Statistik Harga Produsen Pertanian Subsektor Tanaman Pangan, Hortikultura dan Perkebunan Rakyat. Badan Pusat Statistik Provinsi Jawa Tengah.

Farooq, M., Kobayashi, O., Ito, A.W., dan R. Serraj. 2010. Broader Leaves Result in Better Performance of Indica Rice Under Drought Strss. Journal of Plant Physiol 167(13) : 1066 - 1075.

Firmansyah, E. Kurnoiasih, B. dan Indradewa, D. 2016. Respon Varietas Padi Tahan Salin Terhadap Beberapa Durasi Genangan dengan Tingkat Salinitas Berbeda. Artikel Ilmiah 2016 (1) : 50 62.

Kadekoh, I. 2002. Pola Pertumbuhan Kacang Tanah (Arachis hipogeal L,) Dengan Jarak Tanam Bervariasi Dalam Sistem Tumpangsari Dengan
Jagung Pada Musim Kemarau. Jurnal Agrista 6 (1) : $63-70$.

Kristanto, B.A., Indradewa, D., Ma'as, A. dan Sutrisno, R.D. 2014. Penuaan Daun, Kandungan Klorofil Daun dan Hasil Biji Sorgum Manis (Sorghum bicolor L, Moench) di Bawah Kondisi Cekaman Kekeringan. Jurnal Agro 6 (1) : 38 - 49.

Maimunah, Rusmayadi, G. dan Langai, B.F. 2018. Pertumbuhan dan HasilDua Varietas Tanaman Kedelai (Glycine max L,) Dibawah Kondisi Cekaman Kekeringan pada Berbagai Stadia Tumbuh. Enviro Scienteae of Journal 14 (3) : 211 $-221$.

Marsha, N.D., Aini, N. dan Sumarni, T. 2014. Pengaruh Frekuensi dan Volume Pemberian Air pada Pertumbuhan Tanaman Crotalaria mucronata Desv. Jurnal Produksi Tanaman 2 (8) : $673-678$

Maulana, M.R. 2018.Analisis Karakteristik Fisiologi dan Pertumbuhan Tanaman Kedelai (Glycine max L,) Terhadap Perimbangan Pupuk dan Populasi Tanaman pada Sistem Tumpangsari Tebu dan Kedelai. [Skripsi]. Fakultas Pertanian Universitas Muhammadiyah Jember.

Milianda . W. 2020. Analisis Pertumbuhan Padi (Oryza sativa L) Varitas Situbagendit pada Berbagai Dosis Nitrogen dan Fosfor pada Lahan Sawah Tadah Hujan. [Skripsi]. Fakultas Pertanian Universitas Tunas Pembangunan. Surakarta.

Mursidah. 2005. Perkembangan Produksi Kedelai Nasional dan Upaya Pengembangan Di Provinsi Kalimantan Timur. Jurnal EPP. 2(1): 39-45.

Nasrudin dan Firmansyah, E. 2020. Analisis Pertumbuhan Tanaman Padi Varietas IPB 4S pada Media Tanam dengan Tingkat Cekaman Kekeringan Berbeda. Jurnal Galung Tropika 9 (2) : $154-162$.

Ningrum, W.M. 2011. Analisis Pertumbuhan Kedelai (Glycine soja) di Bawah Cekaman Kekeringan. [Skripsi]. Departemen Agronomi dan Hortikultura Fakultas Pertanian Intitut Pertanian Bogor.

Permadi, K. 2014. Implementasi Pupuk N, P, dan K untuk Mendukung Swasembada Kedelai. Jurnal Agrotrop, 4 (1): 1-6.

Pramanda, T. 2019. Analisis Pertumbuhan Tanaman Kedelai (Glycine soja L,) Terhadap Pemberian Urins Kambing dan Variasi Jarak Tanam. 
JURNAL ILMIAH AGRINECA

ISSN : 2721-074X (Online) - 2301-6698 (Print)

Available on : http://ejournal.utp.ac.id/index.php/AFP/index

This is Under CC BY SA Licence

[Skripsi]. Fakultas Pertanian Universitas

Muhammadiyah Sumatera Utara.

Putinella, J. A. 2011. Perbaikan Sifat Fisik Tanah Regosol Dan Pertumbuhan Tanaman Sawi (Brassica Juncea L.) Akibat Pemberian Bokashi Ela Sagu Dan Pupuk Urea. Jurnal Budidaya Pertanian. 7(1): 35-40.

Sakya, A.T., Sulistyaningsih, Indradewa, D. dan Parwanto. 2015. Tanggapan Distribusi Asimilat danLuas Daun Spesifik Tanaman Tomat Terhadap Aplikasi ZnSO4 pada Dua Interval Penyiraman. Jurnal Hortikultura 25 (4) : 311 317.

Santoso, K. dan Sitawati. 2018. Pengaruh Jumlah Populasi Per Lubang Tanam dan Interval Pengairan Terhadap Pertumbuhan Tanaman Selada Wangi (Lactuca sativa var. Longfolia) dalam Sintem Vertikultur. Jurnal Produksi Tanaman 6(9) : $2148-2156$.

Sari. F.C.W. 2008. Analisis Pertumbuhan Ubi Jalar (Ipomea batatas L,) dan Tanaman Nanas (Ananas comosus L,) Dalam Sistem Tumpangsari. [Skripsi]. Fakultas Pertanian Universitas Sebelas Maret.

Suhartono. R. A, Zm Zaed Sidqi, Khoiruddin. Ach. 2008. Pengaruh Interval Pemberian Air Terhadap Pertumbuhan dan Hasil Kedelai (Glycine max (L.)Merril) Pada Berbagai Jenis Tanah. [Skripsi]. Universitas Trunojoyo.

Sulistyono, E., Suwarno., Lubis, I. dan Sehendar, D. 2012. Pengaruh Frekuensi Irigasi Terhadap Pertumbuhan dan Produksi Lima Galur Padi Sawah. Jurnal Agrovigor 5 (1) : $1-8$.

Suryaningsih. R, Purwanto. E, dan Sumiyati. 2016. Analisis Pertumbuhan Beberapa Varietas Kedelai pada Perbedaan Intensitas Cekaman Kekeringan. Jurnal Agrosains 18 (2): 33-37. Universitas Sebelas Maret.

Widiatmoko, T., Agustono, T. dan M. Imania. 2012. Pertumbuhan dan Hasil Beberapa Genotip Kedelai Berbiji Besar pada Cekaman Kekeringan di Berbagai Stadia Pertumbuhan. Jurnal Agrin 16 (1) : $66-79$.

Zulfita, D. 2012. Kajian Fisiologi Tanaman Lidah Buaya Dengan Pemotongan Ujung Pelepah pada Kondisi Cekaman Kekeringan. Jurnal Perkebunan dan Lahan Tropika 2 (1) :7 - 14. 